\title{
1 Limit of Detection for Rapid Antigen Testing of the SARS-CoV-2 Omicron Variant
}

3 Sydney Stanley ${ }^{1}$, Donald J. Hamel ${ }^{1}$, Ian D. Wolf ${ }^{1}$, Stefan Riedel ${ }^{2,3}$, Sanjucta Dutta ${ }^{2}$, Annie

4 Cheng $^{2}$, James E. Kirby*\#2,3, Phyllis J. Kanki*\#1

$6 \quad{ }^{1}$ Department of Immunology and Infectious Diseases, Harvard T.H. Chan School of Public

7 Health, Boston, Massachusetts, USA

$8 \quad{ }^{2}$ Beth Israel Deaconess Medical Center, Boston, Massachusetts, USA

$9 \quad{ }^{3}$ Harvard Medical School, Boston, Massachusetts, USA

*Co-Senior Authors

12

Address for correspondence:

14 Phyllis J. Kanki, DVM, PhD

15651 Huntington Avenue

16 FXB Building, Room 405B

17 Boston, Massachusetts 02115

$18 \quad 617.432 .1267$

19 pkanki@hsph.harvard.edu

21 James E. Kirby, MD

22 Beth Israel Deaconess Medical Center

23330 Brookline Avenue - YA309

24 Boston MA 02215

$25 \quad 617-667-3648$

26 jekirby@bidmc.harvard.edu

Keywords: COVID-19, SARS-CoV-2, antigen test, Omicron, limit of detection, analytical

31 sensitivity 
medRxiv preprint doi: https://doi.org/10.1101/2022.01.28.22269968; this version posted January 30, 2022. The copyright holder for this preprint (which was not certified by peer review) is the author/funder, who has granted medRxiv a license to display the preprint in perpetuity.

It is made available under a CC-BY-NC-ND 4.0 International license .

\section{Abstract}

34 There has been debate in the literature about the ability of antigen tests to detect the SARS-CoV-

352 Omicron variant including indication on the US Food and Drug administration website that

36 antigen tests may have lower sensitivity for the Omicron variant without provision of data or the

37 potential scale of the issue (see https:/www.fda.gov/medical-devices/coronavirus-covid-19-and-

38 medical-devices/sars-cov-2-viral-mutations-impact-covid-19-tests _ omicronvariantimpact,

39 accessed 1/27/2022). Here we determined the limit of detection (LoD) for the Omicron variant

40 compared with the WA1 strain used for LoD studies described in the Instructions for Use for all

41 Emergency Use Authorization (EUA)-approved antigen tests. Using live virus (to avoid artifactual

42 findings potentially obtained with gamma-irradiated or heat-killed virus) quantified by plaque

43 forming units (PFU), we examined the analytical sensitivity of three antigen tests widely used in

44 the United States: the Abbott Binax Now, the AccessBio CareStart, and LumiraDx antigen tests.

45 We found that the 95\% detection threshold (LoD) for antigen tests was at least as good for Omicron

46 as for the WA1 strain. Furthermore, the relationship of genome copies to plaque forming units for

47 Omicron and WA1 overlap. Therefore, the LoD equivalency also applies if the quantitative

48 comparator is genome copies determined from live virus preparations. Taken together, our data

49 support the continued ability of the antigen tests examined to detect the Omicron variant.

50

51

52 
medRxiv preprint doi: https://doi.org/10.1101/2022.01.28.22269968; this version posted January 30, 2022. The copyright holder for this preprint (which was not certified by peer review) is the author/funder, who has granted medRxiv a license to display the preprint in perpetuity. It is made available under a CC-BY-NC-ND 4.0 International license .

To bolster COVID-19 pandemic mitigation efforts, the U.S. Food and Drug Administration

55 (FDA) issued Emergency Use Authorization (EUA) for easy-to-use rapid antigen tests

56 instrumental for diagnosis and surveillance of SARS-CoV-2 infection (1-2). Unlike sensitive

57 molecular tests that detect multiple SARS-CoV-2 genes, antigen tests target a singular yet

58 genetically-conserved nucleocapsid viral protein (3-6). As the pandemic continues, some

59 hypothesized that new SARS-CoV-2 variants might compromise antigen test performance. This

60 concern heightened with the spread of Omicron, the B.1.1.529 variant of concern (VoC) that

61 caused $99.5 \%$ of SARS-CoV-2 infections in the United States early 2022 (7-8). Beyond the

62 striking 36 amino acid mutations in the spike protein, Omicron also harbors P13L, $\Delta 31-33$,

63 R203K, and G204R nucleocapsid mutations (9). The limit of detection (LoD) of many FDA EUA

64 antigen tests were established with gamma-irradiated or heat-inactivated preparations of the USA

65 WA1/2020 (WA1) reference strain (13) lacking nucleocapsid mutations. This includes at-home

66 lateral flow tests like the BinaxNOW COVID-19 Ag Card (Abbott Diagnostics Scarborough, Inc.,

67 Scarborough, ME) and the CareStart COVID-19 Antigen Home Test (Access Bio, Inc., Somerset,

68 NJ), and the LumiraDx SARS-CoV-2 Ag Test (LumiraDx UK Ltd., Alloa, Great Britain), a

69 microfluidic immunofluorescence assay for clinical laboratory testing (10-12). In the present

70 study, we used cultured plaque-titered live Omicron and WA1 virus to assess differences in the

71 LoD with the Binax, CareStart, and LumiraDx tests.

72

The WA1 (13) and Omicron lh01 (NCBI accession OL719310) virus were titered with

73 standard plaque (13) and calibrated RT-qPCR (14) assays. Ten-fold serial dilutions in PBS ranging

74 from $2.5 \times 10^{4}$ to 2.5 plaque forming units $(\mathrm{PFU}) / \mathrm{mL}$ were applied to swabs in $50 \mathrm{uL}$ volumes and

75 tested in triplicate according to manufacturer instructions (10-12). Binax and CareStart kits

76 contained all required consumables; iClean foam swabs (Supera CY-FS742, Houston, TX) were 
77 used with the LumiraDx test. After identifying the lowest 10-fold dilution with three replicate

78 positive tests, we iteratively tested 3 -fold dilutions around this concentration until identifying the

79 lowest dilution (the LoD) in which at least 19 of 20 replicates ( $\geq 95 \%)$ were positive.

80 The LumiraDx LoD for both Omicron and WA1 was $2.5 \times 10^{2} \mathrm{PFU} / \mathrm{mL}(12.5 \mathrm{PFU} / \mathrm{swab}$ or

$811.0 \times 10^{6}$ genome copies (gc)/swab) (Fig. 1). The Binax LoD was $8.3 \times 10^{1} \mathrm{PFU} / \mathrm{mL}(4.2 \mathrm{PFU} / \mathrm{swab}$,

$\left.823.4 \times 10^{5} \mathrm{gc} / \mathrm{swab}\right)$ and $2.5 \times 10^{2} \mathrm{PFU} / \mathrm{mL}\left(12.5 \mathrm{PFU} / \mathrm{swab}, 1.0 \times 10^{6} \mathrm{gc} / \mathrm{swab}\right)$ for Omicron and WA1,

83 respectively. The CareStart LoD was $2.8 \times 10^{3} \mathrm{PFU} / \mathrm{mL}\left(1.4 \times 10^{2} \mathrm{PFU} / \mathrm{swab}, 1.1 \times 10^{7} \mathrm{gc} / \mathrm{swab}\right)$ and

$848.3 \times 10^{3} \mathrm{PFU} / \mathrm{mL}\left(4.2 \times 10^{2} \mathrm{PFU} / \mathrm{swab}, 3.5 \times 10^{7} \mathrm{gc} / \mathrm{swab}\right)$ for Omicron and WA1, respectively. The

85 nearly identical relationship of PFU to genome copies for each variant indicates that the Omicron

86 variant mutations do not change undelrying diagnostic relationships and paramaters (Figure 2).

87 Our use of live virus, analyte volume, and swab type may explain the slight discrepancy with the

88 manufacturers' LoDs. Our findings are consistent with similar investigations, but these studies fell

89 short of the FDA's EUA requirement of $20 \mathrm{LoD}$ replicates or included tests unavailable in the

90 United States (15-17). In all, we demonstrate that the rapid antigen tests evaluated detect Omicron

91 effectively, allaying concerns on the impact of the nucleocapsid mutations. Rapid antigen tests

92 remain critical public health tools towards reducing SARS-CoV-2 variant transmission. 
medRxiv preprint doi: https://doi.org/10.1101/2022.01.28.22269968; this version posted January 30, 2022. The copyright holder for this preprint (which was not certified by peer review) is the author/funder, who has granted medRxiv a license to display the preprint in perpetuity.

It is made available under a CC-BY-NC-ND 4.0 International license.

93 Figure 1. Limit of detection of the antigen tests. Limit of detection (LoD) in PFU/mL determined

94 in our analysis (bars). Dotted lines reference the manufacturer reported LoD in respective

95 Instructions for Use (IFU) documents (10-12), converted from $\mathrm{TCID}_{50} / \mathrm{mL}$ to $\mathrm{PFU} / \mathrm{mL}$ by

96 multiplying the $\mathrm{TCID}_{50} / \mathrm{mL}$ by 0.7 , a standard conversion based on the Poisson distribution:

97 LumiraDx (32 TCID $\left.50 / \mathrm{mL}, 2.2 \times 10^{1} \mathrm{PFU} / \mathrm{mL}\right)$; Binax (140 TCID $\left.50 / \mathrm{mL}, 9.8 \times 10^{1} \mathrm{PFU} / \mathrm{mL}\right)$,

98 CareStart $\left(800 \mathrm{TCID}_{50} / \mathrm{mL}, 5.6 \times 10^{2} \mathrm{PFU} / \mathrm{mL}\right)$.

99

Antigen Test Limit of Detection

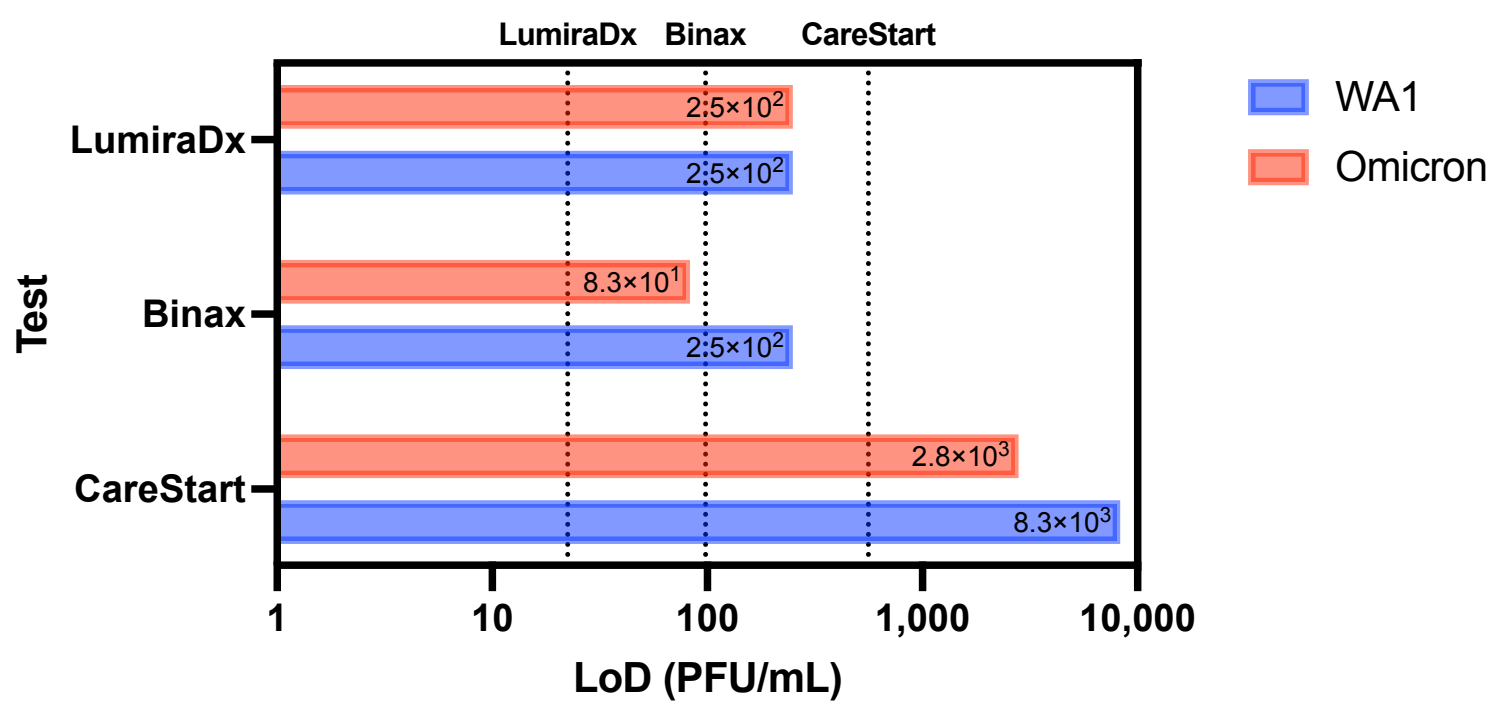


medRxiv preprint doi: https://doi.org/10.1101/2022.01.28.22269968; this version posted January 30, 2022. The copyright holder for this preprint (which was not certified by peer review) is the author/funder, who has granted medRxiv a license to display the preprint in perpetuity. It is made available under a CC-BY-NC-ND 4.0 International license.

101 Figure 2. Correlation of PFU/mL and viral load in genome copies $/ \mathbf{m L}$. Stocks of each strain

102 was serially diluted 10-fold in PBS and analyzed by PFU (13) and calibrated RT-qPCR assays

103 (14). Both axes are on a $\log 10$ scale.

104

105

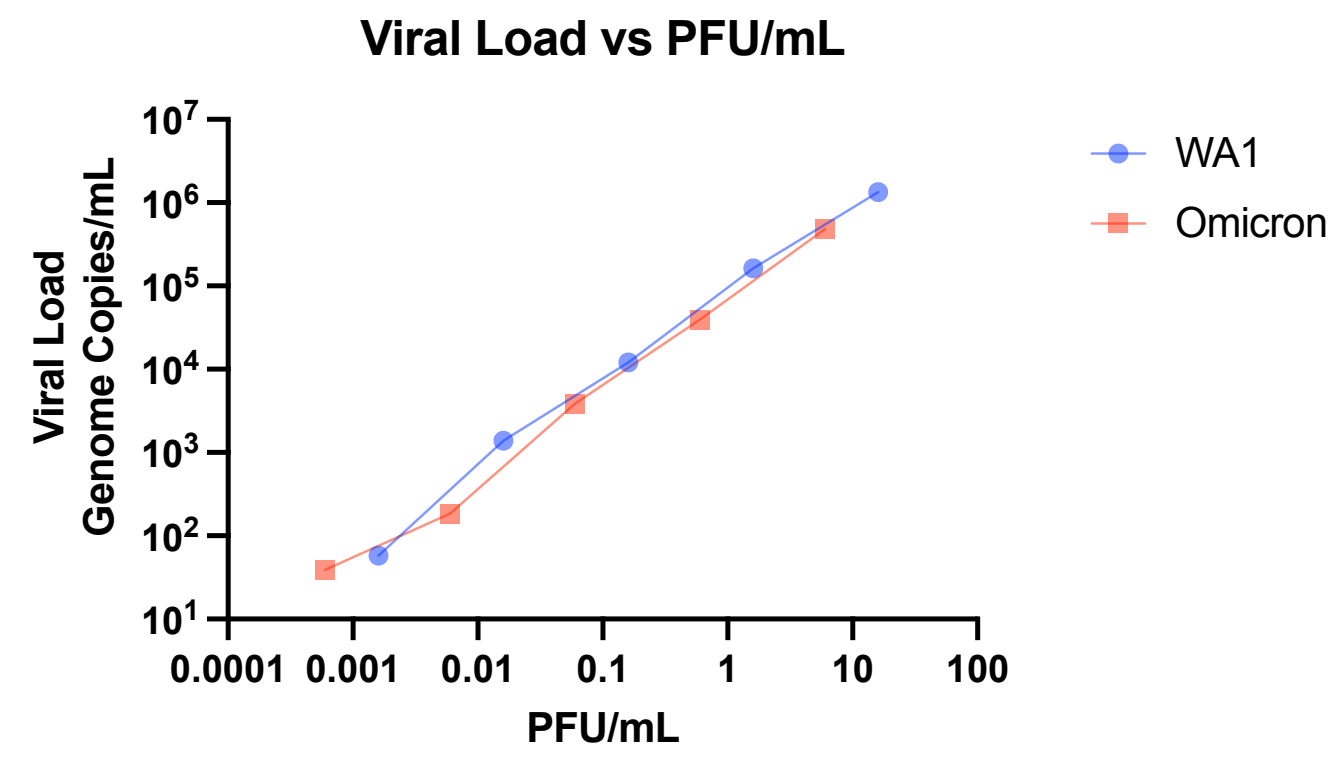


medRxiv preprint doi: https://doi.org/10.1101/2022.01.28.22269968; this version posted January 30, 2022. The copyright holder for this preprint (which was not certified by peer review) is the author/funder, who has granted medRxiv a license to display the preprint in perpetuity. It is made available under a CC-BY-NC-ND 4.0 International license .

\section{References}

1. The U.S. Food and Drug Administration. In Vitro Diagnostics EUAs - Antigen Diagnostic Tests for SARS-CoV-2. Available at: https://www.fda.gov/medical-devices/coronavirusdisease-2019-covid-19-emergency-use-authorizations-medical-devices/in-vitrodiagnostics-euas-antigen-diagnostic-tests-sars-cov-2. Accessed 24 January 2022.

2. The Centers for Disease Control and Prevention. Overview of Testing for SARS-CoV-2, the virus that causes COVID-19. Available at: https://www.cdc.gov/coronavirus/2019ncov/hcp/testing-overview.html. Accessed 24 January 2022.

3. Jegerlehner S, Suter-Riniker F, Jent P, Bittel P, Nagler M. 2021. Diagnostic accuracy of a SARS-CoV-2 rapid antigen test in real-life clinical settings. Int J Infect Dis 109:118-122.

4. Allan-Blitz LT, Klausner JD. 2021. A Real-World Comparison of SARS-CoV-2 Rapid Antigen Testing versus PCR Testing in Florida. J Clin Microbiol 59(10):e0110721.

5. Pray IW, Ford L, Cole D, Lee C, Bigouette JP, Abedi GR, Bushman D, Delahoy MJ, Currie D, Cherney B, Kirby M, Fajardo G, Caudill M, Langolf K, Kahrs J, Kelly P, Pitts C, Lim A, Aulik N, Tamin A, Harcourt JL, Queen K, Zhang J, Whitaker B, Browne H, Medrzycki M, Shewmaker P, Folster J, Bankamp B, Bowen MD, Thornburg NJ, Goffard K, Limbago B, Bateman A, Tate JE, Gieryn D, Kirking HL, Westergaard R, Killerby M, CDC COVID19 Surge Laboratory Group. 2021. Performance of an Antigen-Based Test for Asymptomatic and Symptomatic SARS-CoV-2 Testing at Two University Campuses Wisconsin, September-October 2020. MMWR Morb Mortal Wkly Rep. 2021 Jan 1 69(5152):1642-1647. 
medRxiv preprint doi: https://doi.org/10.1101/2022.01.28.22269968; this version posted January 30, 2022. The copyright holder for this preprint (which was not certified by peer review) is the author/funder, who has granted medRxiv a license to display the preprint in perpetuity. It is made available under a CC-BY-NC-ND 4.0 International license .

6. Grifoni A, Sidney J, Zhang Y, Scheuermann RH, Peters B, Sette A. 2020. A Sequence Homology and Bioinformatic Approach Can Predict Candidate Targets for Immune Responses to SARS-CoV-2. Cell Host Microbe 27(4):671-680.e2.

7. The World Health Organization. Classification of Omicron (B.1.1.529): SARS-CoV-2 Variant of Concern. Available at: https://www.who.int/news/item/26-11-2021classification-of-omicron-(b.1.1.529)-sars-cov-2-variant-of-concern. Accessed 21 January 2022.

8. The Centers for Disease Control and Prevention. Monitoring Variant Proportions. Available at: https://covid.cdc.gov/covid-data-tracker/\#variant-proportions. Accessed 21 January 2022.

9. Nextstrain. Genomic epidemiology of novel coronavirus - Global subsampling. Available at: https://nextstrain.org/ncov/gisaid/global. Accessed 21 January 2022.

10. SARS-CoV-2 Antigen (Ag) Product Insert - LumiraDx. Available at: https://www.lumiradx.com/assets/pdfs/covid-19-antigen-test/sars-cov-2-antigen-productinsert/sars-cov-2-ag-test-strip-product-insert-eua.pdf?v=6. Accessed 21 January 2022.

11. BinaxNOW COVID-19 Ag Card - Instructions for Use. Available at: https://www.fda.gov/media/141570/download. Accessed 21 January 2022.

12. CareStart COVID-19 Antigen test - Instructions for Use. Available at https://www.fda.gov/media/142919/download. Accessed 21 January 2022.

13. Harcourt J, Tamin A, Lu X, Kamili S, Sakthivel SK, Murray J, Queen K, Tao Y, Paden CR, Zhang J, Li Y, Uehara A, Wang H, Goldsmith C, Bullock HA, Wang L, Whitaker B, Lynch B, Gautam R, Schindewolf C, Lokugamage KG, Scharton D, Plante JA, Mirchandani D, Widen SG, Narayanan K, Makino S, Ksiazek TG, Plante KS, Weaver SC, 
medRxiv preprint doi: https://doi.org/10.1101/2022.01.28.22269968; this version posted January 30, 2022. The copyright holder for this preprint (which was not certified by peer review) is the author/funder, who has granted medRxiv a license to display the preprint in perpetuity. It is made available under a CC-BY-NC-ND 4.0 International license .

Lindstrom S, Tong S, Menachery VD, Thornburg NJ. 2020. Severe Acute Respiratory Infect Dis 26(6):1266-1273.

14. Kirby JE, Riedel S, Dutta S, Arnaout R, Cheng A, Ditelberg S, Donald J. Hamel, Charlotte A. Chang, Phyllis J. Kanki. 2021. SARS-CoV-2 Antigen Tests Predict Infectivity Based on Viral Culture: Comparison of Antigen, PCR Viral Load, and Viral Culture Testing on a Large Sample Cohort. medRxiv 2021 https://doi.org/10.1101/2021.12.22.21268274.

15. Regan J, Flynn JP, Choudhary MC, Uddin R, Lemieux J, Boucau J, Bhattacharyya RP, Barczak AK, Li JZ, Siedner MJ. 2021. Detection of the omicron variant virus with the Abbott BinaxNow SARS-CoV-2 Rapid Antigen Assay. medRxiv https://doi.org/10.1101/2021.12.22.21268219.

16. Bekliz M, Perez-Rodriguez F, Puhach O, Adea K, Melancia SM, Baggio S, Corvaglia AR, Jacquerioz-Bausch F, Alvarez C, Essaidi-Laziosi M, Escadafal C, Kaiser L, Eckerle I. 2022. Sensitivity of SARS-CoV-2 antigen-detecting rapid tests for Omicron variant. medRxiv https://doi.org/10.1101/2021.12.18.21268018. DA. 2021. Assessment of the analytical sensitivity of ten lateral flow devices against the SARS-CoV-2 omicron variant. J Clin Microbiol jcm-02479. 